ISSN:2149-178X

Volume: 7 Issue: 14 Year: 2021

\title{
Araştırıcı Sanat Eleştirisi ve Bir Sanat Eleştirisi Örneği
}

\section{Dr. Öğr. Üyesi Gülsevim CAN GÜRBÜZ}

\author{
Kütahya Dumlupınar Üniversitesi
}

Güzel Sanatlar Fakültesi

ORCID:0000-0003-2222-2635

\section{Özet}

Sanat eleştirisi, bir sanat üretiminin değerini arayan inceleme, tespit, zihinsel bir etkinlik şeklinde betimlenebilir. Bir sanat eleştirisinde, belirlenen sanat üretimine yönelik farklı inceleme stratejileri ve yöntemler kullanılabilir. Çalışmada yöntem olarak belirlenen Edmund Burke Feldman'ın “araştırıcı sanat eleştirisi” eleştiri modeli de bunlardan biridir.

Çalışmada genel olarak araştırıcı sanat eleştirisi düşünce sistemini incelemek, özelde de Paula Rego'ya ait olan "The Maids" (Hizmetçiler) adlı esere bu sistem ile eleştiride bulunmak amaçlanmıştır. Bunun için, esere yönelik "betimleme, çözümleme, yorumlama ve yarg1-değerlendirme" evreleri oluşturulmuştur. Betimleme ve çözümleme alt başlıkları, "bulgular bölümü” olarak yer almaktadır. Bulgular bölümündeki verilerin birbirleri ile ilişkilerini, yorumlanmalarını ve değerlendirilmelerini içeren diğer iki alt başlık da “tartışma bölümü” olarak ele alınmıştır.

Anahtar Kelimeler: Sanat eleştirisi, Feldman'ın eleştiri modeli, Betimleme, Çözümleme, Yorumlama, Yarg1, Değerlendirme, Paula Rego, The Maids, Hizmetçiler

\footnotetext{
Abstract

Art criticism can be described as an examination, determination, and mental activity that seeks the value of an art work. In an art criticism, different analysis strategies and methods can be chosen for the related
} 
artwork. Edmund Burke Feldman's "researching art criticism" criticism model, which is determined as a method in thearticle, is one of them.

In th earticle, it is aimed to examine the method of "researching art criticism" in general, and in particular, to criticize Paula Rego's artwork called "The Maids" with this method. For this criticism, "description, analysis, interpretation and judgment-evaluation" phases for the work were formed. Description and analysis subheadings are included in the "results section". The other two subheadings, which include the relationship, interpretation and evaluation of the results section's informations, are also considered as the “discussion section".

Keywords: Art criticism, Feldman model of criticism, Description, Analysis, İnterpretation, Judgment, Evaluation, Paula Rego, The Maids

\section{Giriş}

Eleştirinin, ilgili “şey”in değerine yönelik farklı parametrelerle gerçekleşen zihinsel bir etkinlik olduğu belirtilebilir. Sanat eleştirmeni, tercih ettiği sanat eleştirisi yöntemi, ilgili esere dair bilgileri, beğenisi, estetik duyarlılı̆̆ı ya da eğitim-çalışma alanına dek dayandırılabilecek parametreler doğrultusunda bir yol çizerek incelemede bulunur. Bu yolun, nesnel ve güvenilir bilgilerle başladı̆̆ 1 , fikirler geliştirildikçe öznel değerlendirmeye doğru evrildiği belirtilebilir. Öte yandan eleştiri, sanat üretimini izleyici için daha anlaşılır hale getirir. Sanatın kapsamının genişlediği güncel sanat dünyasındaki gelişmeler neticesinde, eleştiri üzerine yapılan çalışmalar da yenilenmekte ve bu durum yeni okumalara zemin hazırlamakladır.

\section{Araştırıcı Sanat Eleştirisi}

Sanat eleştirisinde çeşitli yöntemler kullanılmaktadır. Edmund Burke Feldman'ın öne sürdüğü “araştırıcı sanat eleştirisi” düşünce sistemi de bunlardan birisidir. Feldman eleştiri türlerini, Akademik Eleştiri, Basın Eleştirisi, Popüler Eleştiri, Pedagojik Eleştiri olarak sınıflandırmıştır. 
Edmund Feldman ve Don Woods, sanat eleştirisi davranışının bir sistem içerisinde ele alındığı zaman öğretilebileceğine inanmaktadır. Yazarlar, Feldman'ın görsel sanatı yorumlamaya yönelik sistematik yaklaşımının, tüm eserlere ve görsel deneyim türlerine uyarlanabileceğini belirtmiştir. Araştırıcı sanat eleştirisi yöntemi, "betimleme, çözümleme, yorumlama ve yargı (değerlendirme)" basamakları ile oluşturulur. Betimleme evresi sanat eserinin reel (gerçek, görünen) boyutunu tarafsız olarak gözler önüne serer. Feldman, yöntemin ilk aşaması olan "betimleme"de, bir sanat eserindeki görsel detayların tanımlandığını, isimlendirildiğini ve ayırt edildiğini belirtmiştir. Yöntem buluşsal ve fenomenolojiktir. Eserdeki nesnelerin ve detayların görsel bir envanteri yapılır. Daha fazlasını fark etmek, keşfetmek, karşılaştırmak için, yani görsel detayları ortaya çıkarmak için tasarlanmış yönlendirici sorulara cevaplar aranır. Sanat eleştirisinin ikinci aşamasında biçimsel "çözümleme", yukarıda bahsedilen ikonik kavramlar ve ilişkisel terimler üzerinden, birinci aşamada betimlenen biçimler ve nesneler arasındaki ilişkiler üzerinden incelenerek geliştirilir (Feldman, Woods, 1981, 79).

Çözümleme evresinde ise biçimsel özellikler, sanatsal elemanlar ile ilkeler arasındaki tasarım ilişskileriyle ele alınır. Feldman bu evredeki tartışmayı daha çok sanat eserinin yapısı ve kompozisyonu üzerinde yoğunlaştırmıştır (Cromer, 1990, 43-44). "Yorumlama" evresinde objektif yaklaşıma kişisel düşünceler de dahil olmaya başlar. Bu evre, iki basamaktaki izlenimler 1şı̆̆ında, sanat üretimindeki anlamların farkına varılması evresidir. Sanat üretimi ne anlatmaya çalışmış, bakarken ne hissediyorsunuz, farklı bazı referans çerçeveleri ile incelenmesi gerekir mi gibi sorularla bu basamak, daha özgün ve araştırıcı bir biçimde eserin yorumlandığı bölümdür. Var olan dolaylı anlatımları fark etmek için salt görüntüsel inceleme yeterli değilse, olası dışsal bağlamları, etkenleri, sembolik ifadeler hakkında yazılmış metinleri incelemek faydalı olacaktır. Ontolojik açıdan bakıldığında, sanatın ön yapı incelemesinden arka yapı incelemesine doğru bir yol çizilmeye başlandığı söylenebilir.

Yargı ise eleştirinin son aşamasıdır. Eleştirinin üçüncü ve dördüncü adımları, yorumlama ve yargı (değerlendirme), görsel formların ve ilişkilerin tanımlanmasının ve analizinin ötesine geçerek daha yüksek anlam seviyelerine götürür (Feldman, Woods, 1981, 79). Daha önceki evrelerde elde edilen gerçek veriler, görsel veriler ve anlatımcı verilerin kullanıldığı aşama olan "yargı"da, sanat üretimi hakkında varılan sonuçlar paylaşılır. Bu eser neden güzeldir, hangi sanat anlayışına, kuramına yatkındır gibi soruların cevabı bu aşamada verilir (Boydaş, 2004, 47).Yargı evresinde ele 
alınabilecek belli başlı dört ana sanat kuramı vardır. Bunlar; Yansıtmacı Sanat Kuramı, Anlatımcı Sanat Kuramı, Biçimci Sanat Kuramı ve Duygusal Etki Kuramıdır. Temel sanat kuramları, sanatçı, sanat ürünü, sanat tüketicisi ve çevre olarak dört öğeden birine yönelir ve bir kuram daha çok öne çıkan bir öğeyi ele alır (Ulger, 2015, 3-12). Böylelikle bir sanat üretimi estetik açıdan duyumsanırken, özellikle yargıda bulunma ediminde, kuramlardan yararlanılabilir. Yansıtmacı Sanat Kuramı'nı sanat üretiminin konusunun gerçekçi bir biçimde aktarımı olarak ele almak mümkündür. Anlatımcı Sanat Kuramı, sanatçının sanat üretimi ile aktarmak istediği duygunun, içeriğin ön planda olduğu bir kuramdır. Biçimci Sanat Kuramı'nda, içerik ya da anlatı yerine sanat üretiminin sahip olduğu öğeleri, görünümü ön plana çıkar. Duygusal Etki Kuramı sanat izleyicisine yönelik bir inceleme olanağı verir. Sanatçının sanatı yoluyla aktardıklarının, izleyicide (izleyici-okur-tüketici-alımlayıcı) oluşturduğu duygusal, psikolojik etkileri temel alır.

Feldman ve Woods, görsel sanatın (veya başka herhangi bir sanatın) genellikle net bir dil olarak ele alınamaması özelliğinin, anti-bilişselci estetikçilerin sanatın özünde bilişsel olmadığına dair inançlarını desteklemek için vurguladıkları bir özellik olduğunu belirtmiştir. Anti-bilişselci estetikçilerin, görsel sanatın doğal dillerden farklı olarak, genellikle bağlam üzerine kurulu olduğunu iddia ettiklerini aktarmışlardır. Sanat bağımlıdır, doğası gereği belirsiz ve ayrık değildir. Ancak görsel sanat unsurlarının bağlamsal bağımlılığı, Feldman tarzında eleştirel bir yöntem kullanılarak, sanatın eğitsel olarak yararlanılabilen erdemlerinden biri olarak incelenebilir (Feldman, Woods, 1981, 80).

Kırışoğlu, araştırıcı sanat eleştirisi düşünce sisteminin (betimleme, çözümleme, yorumlama ve yargı) evrelerinin, bazı eleştirmenler tarafından farklı sıralanabildiğini belirtmiştir. Bu sıralama sırasıyla; "duyusal, biçimsel, tematik ve teknik" olarak belirtilmiştir. İki sıralama karşılaştırıldığında, evrelerin içeriğinde keskin bir değişikliğin olmadığı görülmektedir. Zaten eleştirmenler bu evreleri nesnel bilgiden yola çıksalar da, kendilerine özgü bir yol ile deneyimleyeceği için ve adlandırmalar onlara genel bir çerçeve sunduğu için, adsal farklılık bir sorun teşkil etmeyecektir (Kırışoğlu, 2002, 132; Karabulut, Karakuzu, Konca, 2008, 91).

Araştırıcı sanat eleştirisi düşünce sistemi tüm eserlere ve görsel deneyim türlerine uyarlanabileceğini gibi, eğitim amaçlı da kullanılabilir. Edmund Burke Feldman ve Don Woods, yöntemin, anaokulları ve dezavantajlı öğrenciler de dahil olmak üzere her yaştan okul çocuklarına başarıyla öğretildiğini aktarırlar. Bu konuda, Georgia Üniversitesi'nde bir pilot çalışma yapılmıştır. 
Sanat eserlerinin reprodüksiyonlarını yorumlamak için ilgili yöntemi kullanmak, dezavantajlı durumdaki birinci sınıf öğrencilerinin, öğrenmeye ve okumaya hazır olmanın değerlendirildiği sözsüz bir test olan Boehm Temel Kavramlar Testi'ndeki son test puanlarını önemli ölçüde iyileştirmiştir. Buradan, okumaya hazırlık programlarının geliştirmeye çalıştığı temel kavramların ve eleştirideki temel kavramların da aynı ikonik kavramlar olduğu ortaya çıkmıştır. Sanat eleştirisinde yapı, şekil, renk, yön, konum, büyüklük, sayı, benzerlik, farklılık, düzenleme, orantı, derinlik ve aşağıda, arkasında, yanında, solunda, üstünde, kenarında, içeride gibi ilişkisel kavramları geliştirmeye çalışır. Richard A. Salome'dan aktaran Feldman ve Woods, okumaya hazırlık programlarında yer alan algısal eğitimin, anaokulu ve birinci sınıf öğrencilerinin sanat çalışmalarında da kullanılabileceğini belirtir. Bu nedenle, yukarıda bahsedilen pilot çalışmanın da gösterdiği gibi, sanat eleştirisi becerileri “okumayı öğrenme”yi kolaylaştırır (Feldman, Woods, 1981, 78-79).

\section{Bir Sanat Eleştirisi Örneği: Hizmetçiler (The Maids)}

Çalışmanın bu bölümünde, Paula Rego'nun 1987 tarihli “The Maids” adlı eserinin incelemesi yer almaktadır. Yöntem olarak "araştırıcı sanat eleştirisi" metodu tercih edilmiştir. Araştırıcı sanat eleştirisi metodunu uygulamak için betimleme, çözümleme, yorum ve yargı evreleri, "bulgular" ve "tartı̧̧a" alt başlıklarıyla kategorize edilerek ele alınmıştır. Çalışmada, eser'in orijinal adı olan "The Maids", Türkçe çevirisi olan "Hizmetçiler” olarak geçmektedir. 


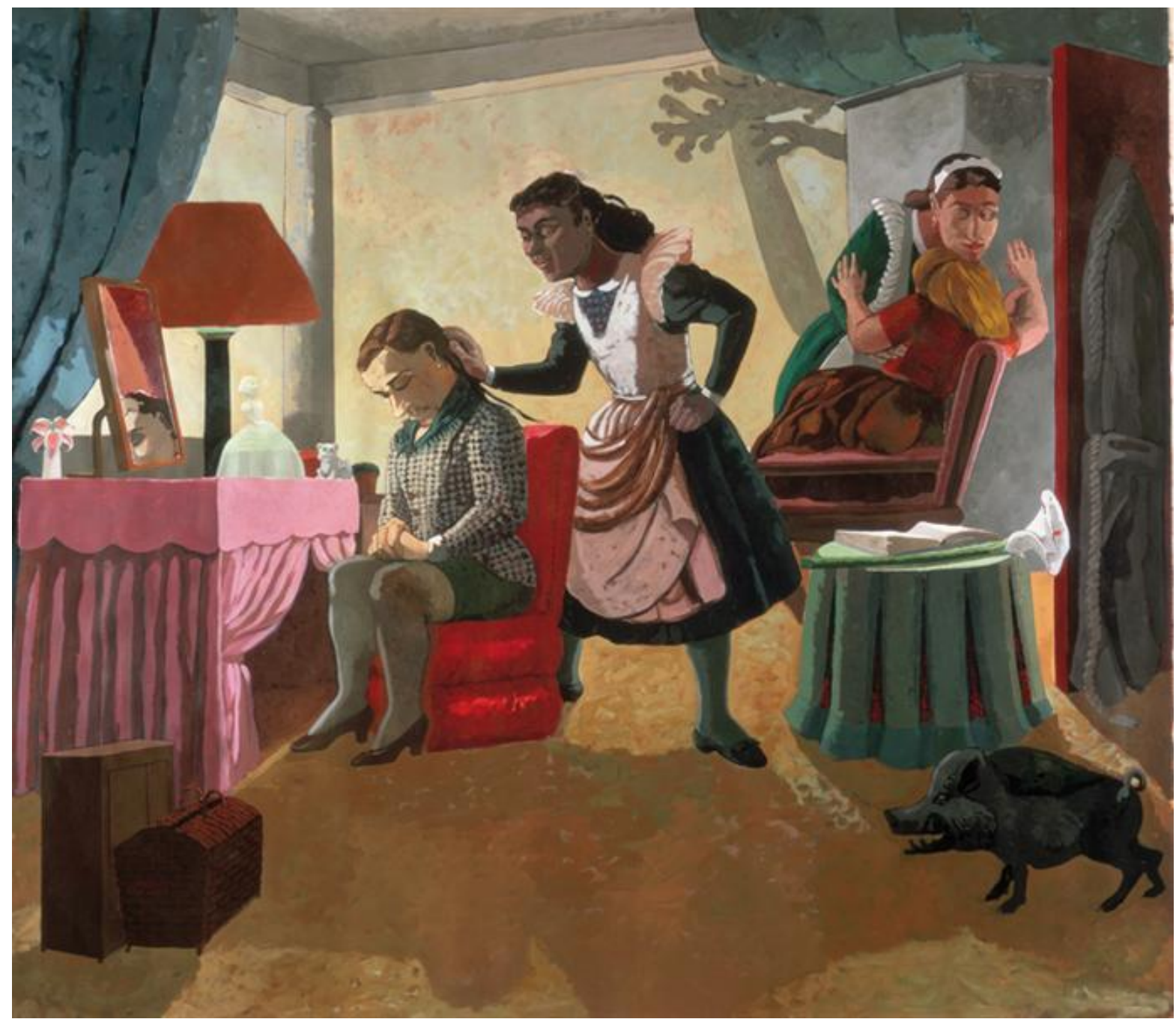

Görsel 1:Paula Rego, The Maids (Hizmetçiler), 1987. (https://www.wikiart.org/en/paularego/the-maids-1987)

\subsection{Bulgular:}

\subsubsection{Betimleme:}

Resimde, kapalı bir mekan içerisinde 4 adet insan figürü bulunmaktadır. Mekanda figürlerin beraberinde bir çok eşya da tasvir edilmiştir. Bu eşyaların görüntüsel benzerlikleri ile; dresuar, ayna, abajur, sandık, kutu, sehpa, perdeler, berjerler, halı, sütunlu duvarlar (ya da duvar gibi 
görünen kapalı pencereler) açık bir kapı, kapı arkasına asılmış kıyafet, açık bir kitap, yapay çiçek, doldurulmuş bir hayvan figürü ve diğer dekorasyon ürünleri oldukları belirtilebilir. Eşyalardan, sunulan mekânın bir yatak odası olduğu anlaşılır. Duvardaki el ve ağaca benzeyen formların da gölge ya da siluet olduğu düşünülmektedir. O halde bu kısım duvar yerine kapalı bir pencere de olabilir.

Figürlerin, giyimleri ve genel biçimsel özellikleri neticesinde kadın oldukları anlaşılmaktadır. Ancak vücut yapılarının kaba olması dolayısıyla figürler maskülen görünmektedirler. Özellikle en solda yer alan figür hermafrodit bir görüntüdedir. Yine figürlerdeki kıyafet göstergelerinden iki figürün hizmetçi olduğu anlaşılır. Resmin adı da bu tanımlamayı destekler. Resmin ön planında, hizmetçi şeklinde betimlenen bir figür diğerinin arkasından tutmaktadır. Arka plandaki iki figürde de bir hareketlilik mevcuttur. İzleyiciye dönük olarak tasvir edilmiş üç insan yüzü vardır.

Mat bej rengi, gri rengi tonları ile oluşturulmuş mekanın çevrelediği figürler ve eşyalar, çoğunlukla canlı renkler ile sunulmuştur. Perde, halı, kıyafetler gibi resmin birçok yerinde farklı dokularla da karşılaşılır.

\subsection{2 Çözümleme}

Kompozisyonda izleyiciye en yakın konumlandırılmış nesnelerin; sağdaki domuza benzer özellikleri olan doldurulmuş hayvan figürü, soldaki birisi sandık görünümlü olan iki kutu olduğu görülür. Mekânın alt sınır çizgileri resimde görülemese de, yer alan birçok birim, öndeki ilgili nesnelerden ortaya doğru perspektifsel bir çizgi varmışçasına sıralanır. Gerek bu çizgisel yerleştirme, gerekse hizmetçi kadın figürün resmin tam ortasında bulunması, bu figürün bir odak noktası gibi öne çıkmasını sağlamıştır. Ayrıca figürlerin konumsal olarak yerleşimi ortada olduğu için, nesnelerin tamamı görülmemesine karşın kompozisyon kapalıdır.

Zemin ve duvarların pastel renklerinin taban oluşturduğu kompozisyon, ana renklerin, zıt renklerin ve onların tonlarının birlikteliği ile daha dikkat çekici hale gelmiş̧ir. Kırmızı, pembe ve kiremit renklerine, yeşil, tirşe, mavi ve sarı renkleri eşlik etmektedir. Renge eşlik eden dokuların yoğunluğu, hem resmin birimleri arasındaki ayırt edilebilirliği artıran bir unsurdur, hem de resmi 
zenginleştirmiş̧ir. Kıyafetlerin, saçların, masa örtülerinin ve perdelerin doku ve 1şı gölge etkilerinden, diğer birimlere göre daha yumuşak oldukları sezinlenir. Halının etkisi de keza öyledir. Sanatçının üslubundan, firça kullanımından da kaynaklı bu etki, kompozisyondaki nesne ve figürlerin gerçeğine daha yakın olarak algılanabilinmesini sağlamıştır. Ancak hissedilen etüt etkisi, biçim bozma ile, dışavurumsal etki ile kaynaşır ve gerçeğini birebir yansıtan bir görüntü oluşmaz.

Mekânı ve iki figürü abajurun 1şığı, iki figürü ise açık kapıdan sızan ışık aydınlatmaktadır. Böylelikle nispeten loş bir ortam tasvir edilmiş, yer yer gölgeler ön plana çıkarılmıştır. Duvardaki el ve ağaç formlarına benzeyen gölgeler ise dışsal bir ışık kaynağı olduğu düşünülerek eklenmiş olabilir. Çünkü bir başka aydınlatma göstergesi bulunmamaktadır.

Resmin ön planında, hizmetçi görünümlü figür, bir başka figürün arka boyun kısmından tutarak ona direktif verir gibi görünmektedir. Dresuar üzerindeki aynadan, oturan kadının yüzünün diğer kısmı da görünmektedir. Hizmetçi görünümlü figürün yüz ifadesinden soğukkanlılık, boynundan tutulmuş diğer figürün yüz ifadesinden mutsuzluk ve çaresizlik izleyiciye geçmektedir. Arka planda hizmetçi kıyafetiyle tasvir edilmiş diğer kadın, yapısal olarak çocuk gibi görünen, arkası dönük olan figüre sarılmış gibi görünmektedir. İki figür iç içe geçmiştir. İç içe olma durumu, izleyiciye dönük olan yüzün ifadesinden, telkin etme ya da zapt etme anı gibi görünmektedir.

\subsection{Tartışma}

\subsubsection{Yorumlama}

Rego'nun sanat üretimlerinde genellikle kadın figürler öne çıkar, diğer nesne ve figürlerden ayırt edilebilir. Yazar Vera Fonseca, Paula Rego konulu tezinde, onun doğrudan izleyiciye bakan kadın özneleri temsil eden birkaç resmini analiz edeceğini belirterek, sorular sorar. "Bir kadın figürü direkt seyirciye bakarsa, seyirciler, kendi bakışlarıyla mı yakalanır? Seyircinin gücü tehlikeye girer mi? Kadın figür gösteri öznesi mi olur?” Foncesa soruların devamında, kadın figürleri sıklıkla kullanan sanatçının onları birer çini panosuna benzettiğini aktarmıştır. "Liman evlerinde bir çini panomuz olduğunda, normalde aralarında daha büyük figürlü bazı çiniler ayakta durur. Genellikle, 
hizmetçiler veya kadınlar, evin bir tür koruyucusudur. Çiniler gibi, diğerlerinden daha büyüktürler.” Rego, resimlerindeki kadın figürleri, boyalı bir duvarın ortasında büyüklügü ile öne çıkan ve her zaman özel bir varlıkları olan, çinilerden yapılmış kesme figürlere benzetmiştir (Rego in Rosenthal, 2003; 51 aktaran, Fonseca, 2012; 74 ). İlgili resimde de kadın figürler hikayeye yön verircesine öne çıkmaktadır. Oturan iki figür edilgin görünümde olsa da, hizmetçilerin edilgin figürlere yönelimleri ayırt edilir niteliktedir ve izleyiciye bir anlamlandırma kapısı aralar. Yani, resimde sembolik anlamlar barındırdığı düşünülebilecek birçok görüntüsel gösterge olsa da, ön plandaki figürler, anlatı konusunda fikirler geliştirilmesine yatkındır.

Resimdeki renk, doku çeşitliliği gibi unsurlar zengin ve canlı olmasına karşın, ortamın etkisi nispeten soğuktur. Bu etkinin nedeni, yine figürlerin şekli ve yansitılan yüz ifadeleri ile bağlantılandırılabilir. Sol taraftaki hizmetçinin önünde oturan figürün, giyimi itibarıyla evin sahibi olabileceği düşünülür. Resim, hizmetçi, ev sahibine her an bir şey yapacakmış gibi bir hisle seyredilir. Ev sahibinin yüz ifadesinden anlaşılır ki, o da bu hisse sahiptir. Diğer hizmetçi, vücut hareketlerinden anlaşılacağı gibi, çocuk figürüne sarılarak, onu oturduğu yerde zapt etmeye, engellemeye çalışmaktadır. Görüntü iyimser bir sarılmadan çok bir boğuşma anına tanıklık edildiğini düşündürür. İzleyiciye dönük üç adet yüz göstergesinin sahip olduğu soğuk ifadeler de, yüz ifadeleriyle bağlantılı olduğu gözlemlenebilen hizmetçi eylemleri de dikkat çekicidir. Buradan, eylemlerin sıradan birer temastan ziyade resmin kilit göstergeleri olduğu düşünülebilir. Figür göstergelerinin oluşturduğu etki, kaynaklardan elde edilen verilerle de örtüşmektedir.

Hizmetçiler adlı resmin hikayesi, Jean Genet'in The Maids (1947) adlı oyunundaki bir olay üzerine kurgulanmıştır. Hikaye, Papin kardeşler Christine ve Lea'nın gerçek hayattaki cinayet vakasına dayanmaktadır. Kız kardeşler, onları rahatsız eden ve muhtemelen korkutan bir elektrik kesintisinden başka görünür bir neden olmaksızın korkup, evin hanımını ve kızını öldürmüşlerdir. Hikayede, evin erkeğinin olmadığ bir zaman, klostrofobik bir şekilde döşenmiş mekan olduğu aktarılmıştır. Belirsizlik ve tehditkar psikoz, odadaki nesnelerde, resmin içinde yankılanmaktadır (https://www.wikiart.org/en/paula-rego/the-maids-1987). Yazar McEwen, Vera Fonseca ve resim hakkında yazmış diğer yazarlar da ilgili hikayeyi paylaşmışlardır. McEwen, sanatçının masanın üzerinde duran zambak çiçeği göstergesi ile, kurbanların masumiyetine ve başlarının kesilecek olmasına gönderme yaptığını da belirtmiştir (McEwen, 2006; 157). 
Resim, bir oyundan esinlenilerek oluşturulmuş bir hikâyeden ibaret değildir. Deniz Korkmaz ve Düriye Kozlu, bu resmin, diğer birçok resim gibi, Paula'nın öz yaşam öyküsüne ait izler taşıdığını aktarmışlardır. Patterson'dan aktaran Korkmaz ve Kozlu, Paula Rego'nun, babasının işi nedeniyle annesiyle birlikte Londra'ya gitmesi ve henüz küçük bir çocuk iken babaannesi ve büyükbabasının yanında Portekiz'de kalmasının, zor bir süreç geçirmesine neden olduğunu belirtmiştir. Evde daha birçok kişi ile birlikte yaşayan Rego, bu dönemde anlatılan Portekiz folk kültürüne ait masallarla büyümüştür, onlardan etkilenmiş̧ir. Sanatçı bu masalların çocuk imgeleminde kalıcı izler bırakacak nitelikte korkunç ve acımasız olabildiğini belirtmiş̧tir (Korkmaz ve Kozlu, 2017; 86). Yayınlanan röportajlarında sanatçı, kendi çocukluğuna göbek bağıyla bağlanmasının altını çizerken, hikayelerle saatler boyunca fantastik bir dünyada ya da oyun odasında evcilik oynayarak eğlendiğini vurgular (McEwen, 2006; 286). Hizmetçiler resminde de, tiyatro sahnesinin anlatısını, sanatçının geçmişine atıflarda bulunan anlatısı ile kısmen özdeşleştirdiği, hikayeyi içselleştirdiği düşünülmektedir. İçselleştirme durumu, sanatçı ve resim ile ilgili detaylar ile daha anlaşılır hale gelebilir.

Kozlu ve Korkmaz tarafından, sanatçının çocukluk döneminde babasının sıklıkla şehir dışında olması dolayısıyla onunla vakit geçiremediği, annenin, ailede babanın rolünü de üstlendiği aktarılmıştır. Resimde ev sahibinin, yani annenin maskulen görünümü bu faktör ile bağlantılandırılmıştır. Ölüm konusunun ele alınması, küçük yaşta, aynı anda ayrı kaldığı anne ve babasının yokluğu ile ilişkilendirilirken, arkadaki kız çocuğu figürünün kendi varlığına işaret ettiği belirtilmiştir. (Korkmaz ve Kozlu, 2017; 86, 87). Fiona Bradley ise, Rego'nun kadınları kadınsı olmayan, erkeksi, hayvani ya da vahşi varlıklar olarak tasvir etme nedenlerinden birinin, erkek zihnindeki idealize edilmiş kadın tipinden ziyade, fiziksel dünyadaki insanlar olarak kadınların doğal gerçekliğini yansıtmak istemesi olduğunu belirtmiştir (Bradley,1997; 19). Rego'nun açıklamalarından, görünenin ötesinde çıkarılabilecek anlamlar daha irdelenebilir hale gelebilir. Rego, McEwen'ın aktarımına göre, bu resimdeki anne temsili figür için “kim bilir, belki de o travesti bir adamdır" demiştir (McEwen, 2006; 156,163). Bu cinsel tercihe yönelik açıklama, bakış açısına yeni öneriler sunar. Açıklama, sanatçının çocukluğunda annesini babasının yerine koyduğunu belirten düşünceyi, ya da kadınların idealleştirilmiş görüntülerine gönderme yaptığ düşüncesini desteklemekten çok, sanatçının cinsellik, özgürlük, kadın hakları gibi konuları ele aldığı çalışmaları gibi, toplumsal kabullere gönderme yaptığı fikrini destekliyor gibidir. 
Kapının ardına asılmış baba kıyafetinin, baba figürünü dolaylı olarak resme dahil eden bir gösterge olarak ele alınabileceği belirtilebilir. McEwen sağ alt köşedeki doldurulmuş domuz figürünü de aynı şekilde erkek figürü, erkek varlığının temsili ile ilişkilendirmiştir. Fakat domuzun içinin doldurulmuş olmasının, evde bulunmayan erkeğin edilginliğine, güçsüzlüğüne ya da iktidarsızlığına işaret edebileceğini aktarmıştır (McEwen, 2006; 157). Domuzun sembolik karş1lığı konusunda, mitolojik hikayelerden inanç söylemlerine dek, duyulmuş birçok anlatı vardır. Eski Anadolu toplumlarında, yazar McEwen'ın da ilişkilendirdiği gibi erkek tanrılarla ve doğurganlıkla bağlantıs1 olduğuna inanıldığı bilinmektedir. Bunun yanında, baba figürüne gönderme yaptığı düşünülen "domuz ve askıdaki kıyafet" göstergelerinin soluk ve gri olması, resimdeki renkli nesne ve figürlerin yanında ayırt edici bir nitelik haline gelir.

Askıdaki kıyafet cekete benzediği için bir başka düşünceyi tetikleyen bir gösterge olarak da ele alınabilir. Asılı ceket, konusu bir kadının baba figürü olmadan bebek sahibi olması üzerine olan otobiyografik belgesel "Bekleyiş" ile de gündeme gelen, "evde bir erkeğin ceketi asılı olmalı" deyişini hatırlatmaktadır. Hikâyenin sahibi ve belgeselin yönetmeni Aslı Akdağ, evlilik dışı çocuk sahibi olduğu için komşularından birinin bu coğrafyanın halk ağzına ait olan "evde bir erkeğin ceketi asılı olmalı" önerisiyle karşılaşmıştır ve bunu belgesele de aktarmıştır. Bu öneri olumlu ya da olumsuz yanlarıyla tartışılmaya açık hassas bir konudur ve bu çalışmanın konusu değildir. Peki, erkeğe ait bir gösterge, onun varlı̆̆ını hissetmek için yeterli midir? Paula Rego, ceketi, belki de baba figürünü dahil etmekten çok onun yokluğunu sembolize eden bir nesne olarak konumlandırmıştır. Öznesizlik nesneyle pekiştirilmiştir.

İlgili resimde olduğu gibi Rego'nun kompozisyonlarına daha gizemli bir hava veren resimsel öğelerden biri de, figüratif çalışmalarının anlatım gücünü pekiştiren belirgin gölgeleri olmuştur. Resimde kütlesel ayrımlar ve gölgeler dışavurumculuğu arttırırken, canlı ve rahat boya kullanımı, gölgeler aracıllğıyla daha belirgin hale gelmiştir. En arka plandaki ağaca benzeyen gölgelerin, biçimsel katkısının yanı sıra sembolik bir değeri de olabilir. Şöyle ki, bu ağaç formu aynı zamanda parmakları açılmış, bir şeyleri kavrayacak eller gibi keskin bir forma sahiptir. Bu el anımsatması, ön plandaki hizmetçi figürlerin eylemlerine göndermede bulunduğu algısı oluşturmuştur.

Gerçeküstücü ressam Paul Delvaux'un (1897-1994) kadın bedenleri, iskeletler gibi ana formları gölgeler içerisinde, karanlık ve gizemli ortamlarda resmederken, yer yer Rego'nun anlatımı ile ilişki kurduğu belirtilebilir. Diğer yandan, Rego'nun son dönemindeki bazı gölgeli 
kompozisyonları, sanatçı Giorgio de Chirico'nun (1888-1978) metafizikle bağlantılanan, melankolik gölge oyunlarından, uzamlardan oluşan eserleri ile ilgili çağrışımlar yapar. Hatta Rego'nun 1993 tarihli “The Artist in Her Studio” eserinde olduğu gibi, sanatçıya birtakım göndermeler yaptığ da söylenebilir.

\subsubsection{Yarg1}

Paula Rego'nun Hizmetçiler resminin, kişisel olarak, biçimsel açıdan da, anlatısal açıdan da çarpıcı ve kışkırtıcı olduğu düşünülmektedir. Kendisinin gerçekleştirdiği röportajlarda da, kendisi hakkında yazılıp çizilmiş çalışmalarda da, bu çarpma etkisinin izleyicilere dokunduğu görülebilmektedir. Dolayısıyla, bu eleştiri metninin konusu olan "Hizmetçiler" resmi gibi, daha güçlü, net formların ve anlatının yer aldığı resimleri, dışavurumcu ve anlatımcı kurama yatkın olarak nitelendirilebilir. Sanatçının ilk dönem çalışmaları olan, sürrealist, yeni-dadaist etkili, daha çok soyutlamaların olduğu ve biçimci kuram etkileri de bulunan kolajlarını aynı şekilde değerlendirmekse doğru bir tutum olmaz.

Rego'nun sanat üretimlerinin geçmişine dönük bakış açısı, üç ayrı oda içerisinde, kariyerini üç farklı periyoda adamış ve üç ayrı sanatçı olduğu düşünülüp incelenebilir. 1960'lı yıllardaki, sanatçısıyla çok ilgisi olmayan, McEwen'in tabiriyle sıkıcı bir başlangıç olan kes-yapıştır kolaj resimleri sonrasında sanatçı, üç parçalı tablosu Pillowman'i üretmiştir ve takip eden seri resimlerine yönelmiştir. Son dönem baskı ve resimleri daha çok seriler halindedir ve bu dönemi, rahatsız edici tinselliğe, mükemmel bir doruğa ulaşarak tamamlanmıştır. Sanatçının yaratım sürecinin incelenmesi, çocukluğuna bağını, çevresel etkilerden beslenmesini, hayal gücünün feminist çıkışlarını ve yaratımlarının uçarı yanlarıyla birleşmelerini açığa çıkarmaktadır (McEwen, 2006, 286). Maria Manuel Lisboa da 1980'lerin sanatçı için çok önemli olduğunu belirtmiştir. Çünkü Rego'nun çalışmaları bu dönemde önemli ölçüde değişmiştir. Lisboa'ya göre değişim natüralist, mecazlı bir dönüşü ifade eder; "kişisel olanın siyasal tutuculuğun önüne geçerek ön plana çıktığı, ima yoluyla, aile ve cinsel politikaların ötesinde ulusal-politik bir içeriğin olduğu” bir dönüştür. Konu olarak hizmetçinin metrese, bir kızın köpeğe karşı somutlaştırdığ1 tehlike ve tehdidin, öngörülen ölümlerin ve benzeri konuların ele alındığı serilerdir. Lisboa açıklamalarının 
beraberinde The Maids (1987), The Fitting (1990), Time: Past and Present (1990,1991) gibi resimlere ilgi göstermiş ve onları analiz etmiştir. Bu serilerin ortak özelliği, aktörleri arasında ikircikli ve tehditkar bir ilişki olmasıdır (Fonseca, 2012; 27). Üretimlerinin genel olarak (üslup haricindeki) yakınlık kurma noktalarının ise, sanatçının kendi geçmişinden, duygu-durumundan ya da kadın haklarını temel alan ideolojisinden çarpıcı detaylar içermeleri olduğu belirtilebilir.

"Biz neyiz? Etleri sarkarken zamanı dinleyen, hem minimal hem geniş, çift taraflı kadınlarız.

Bulanıklıkların arasında kestirme yollardayız Ve birbirimizi görürüz çünkü, daha az ya da daha çok ağırlıklarla, kendimize dönüşürüz." (Ana Marques Gastao, Paula Rego İle İlgili 25 Şiiri)

\section{Sonuç}

Sanat eleştirisi konusu ile başlayan, Edmund Burke Feldman'ın eleştiri modeli olan “araştırıcı sanat eleştirisi" ile devam eden ve bir eser eleştirisi örneği ile tamamlanan çalışma, öncelikle yönteme yönelik literatür taraması ile bir bilgilenmeyi sağlamıştır.

"Hizmetçiler” adlı eser, "araştırıcı sanat eleştirisi” yöntemi uygulanarak eleştirilmeye çalışılmıştır. $\mathrm{Bu}$ inceleme neticesinde, hem bir resme hangi evrelerle bakılabileceği görülmüş, hem de Paula Rego'nun düşünce dünyası ve üslubu konusunda fikirler edinilmiştir. Çocukluk deneyimlerinin, toplumsal kabullerin, toplumsal ve kişisel durum çatışmalarının, yaşadığı dönemdeki (özellikle de) kadın odaklı problemlerin sanatçıyı etkilediği gözlemlenmiştir.

Sanatçının sanat hayatında yeni bir döneme geçiş yapmasının, 1950'lerden beri yaptığı ilk büyük ölçekli ve tamamen figüratif Hizmetçiler çalışmasıyla ve takip eden bu üslupta çalışmalar ile açıklaştığı görülmüştür. 
Çok figürlü, güçlü ve belirgin formların olduğu bir sahnenin sunulduğu Hizmetçiler resminde, üslubun da getirdiği bir sonuç olarak resmin biçimsel olarak çok şey anlatması, anlatısı konusunda açık olması kaçınılmazdır. Ancak bu net görüntü yer yer yanıltıcı olabilir, ya da yüzeysel kalabilir. Örneğin, “yorumlama” bölümünde "soldaki kadın figürün maskulen görünümü” konusundaki farklı düşünceler ele alınmıştır. Sonunda, güçlü anne figürü görüşlerinin aksine, sanatçının "kim bilir, belki de o travesti bir adamdır" mecazlı söyleyişi paylaşılmışıtır. Maskulen kadın figürü, görüntüsel anlamda en az diğer figürler kadar detaylıdır, ancak görüntüsel özellikleri, onun resmin anlatısına kattıkları hakkında kapsamlı bir çerçeve çizemez. Yani, biçimsel anlatımın derinliğine ulaşabilmek için, ikincil bir anlam düzeyi alt okumalarına ihtiyaç duyulacağı belirtilebilir.

Son olarak, "Tartışma" bölümünde, özellikle "Yargı" alt başlığında sonuç niteliğinde bilgiler paylaşıldığı da belirtilmelidir. Eleştiri objektif bir bakışla gerçekleştirilmeye çalışılır ancak, yorumlama ve yargıda bulunma süreçlerinin yapısı gereği istemsizce öznel değerlendirmeye doğru yöneldiği de eklenebilir. Dolayısıyla bu eser inceleme çalışması, eserin direkt gösterdiğinden, ya da diğer incelemelerden bir başka şeyi işaret eden bir fikir içerebilir.

\section{Kaynaklar}

Boydaş, N. (2004). Sanat Eleştirisine Giriş. Ankara: Gündüz Yayınc1lık.

Bradley, F. (1997). Introduction: Automatic Narratives in Tate Gallery, Paula Rego. London: Tate Publishing.

Cromer, Jim (1990). History, Theory And Practice of Art Criticism in Art Education. Reston V.: National Art Education Association.

Feldman, E. ve Woods, D. (1981). Art Criticism and Reading. The Journal of Aesthetic Education, Vol. 15, No. 4 (October, 1981), s. 75-95.

Karabulut, N.,Karakuzu, M., \& Konca, Y. (2008). Sanat Eğitiminde Pedagojik Eleştiri Yöntemleri. Güzel Sanatlar Enstitüsü Dergisi, (21), 87-111. 
Korkmaz D. Ve Düriye Kozlu D. (2017) Paula Rego ve Resimlerindeki Öz Yaşam Öyküsel Çıkarımlar. Art-e Sanat Dergisi, Cilt 10, Sayı 19, s. 78-95.

McEwen, J. (2006). Paula Rego. London: Phaidon.

Fonseca, V. (2012). Paula Rego, a prospective retrospective: Bodies, Visuality, Becoming. Doktora Tezi, Portekiz.

Paula Rego. https://www.wikiart.org/en/paula-rego/the-maids-1987 internet sitesinden 10.112021 tarihinde alınmıştır. 